\title{
Ethical Dimension of Public Service
}

\author{
Bambang Kusbandrijo ${ }^{1}$, Ni Putu Tirka Widanti ${ }^{2}$ \\ ${ }^{1}$ Untag Surabaya (email: b_kusbandrijo@untag-sby.ac.id), ${ }^{2}$ Ngurah Rai University \\ (email: tirka.widanti@unr.ac.id)
}

\begin{abstract}
The concept of New Public Service emphasizes on that government is responsible to provide fast, easy and inexpensive service to the people as citizen. So far, Government of Indonesia has not been able to provide this service even many services are marked by corruption. Mentality of being served than providing service is still massive. It is because low moral culture of the Civil servants to serve and expert professionalism as civil servant. The low moral quality and professionalism of the Civil Servant cause the service in Indonesia is still complicated and takes long time. This weakness becomes the opportunity for corruption. The right training and recruitment process could minimize corruption potency in law enforcement. Through this training, besides improving individual and institutional moral, it also improved the service competence as required in the context of present public administration.
\end{abstract}

\section{Keywords:}

civil servants; moral quality; professionalism; corruption

\section{Ethics}

Theodore Roosevelt said that "to educate a person in the mind but not in morals is to educate a menace to society." Moral is a teaching of good and bad, concerning human behavior and action. An individual who obeys regulations, rules, and norms in the society is considered appropriate and acting morally. Moral in its realization can be in form of regulations and or principles that are right, good, praiseworthy and noble. Moral can be a loyalty, obedience to values and norms which binds life of social, nation and state. Moral can be a loyalty, obedience to values and norms, it can be differentiated to be divine moral or religion, moral, philosophy, ethical moral, law moral, science moral, etc. Values, norms and moral mutually organize social life in any aspects. According to Hurlock, moral is a behavior appropriate to moral code of social group. The moral itself means procedure, habit, and customs. Moral behavior is controlled by moral concepts or behavior regulation which have become habits for a member of a culture (Hurloch, 1980). Chaplin (Chaplin, 2006), moral refers to character which is appropriate to social rules, or related to law or customs which organize 
behavior. Bertens defined ethics in three meanings, i.e. first, ethics as an ethic code that ethics as a set of principles or moral values, for instance ethic code of international press. Second, ethics as a valued system which is used in human life both in individual and social life. It means values or norms that become guidance for individual or group in organizing their behavior. Third, ethics as moral philosophy (Bertens, 1994).

The discussion of ethics as discussed in this article becomes crucial in the the component of public service when the public service must be principled fast, easy and inexpensive by considering people as citizens (Janet V Denhard, Robert B Denhard, 2003). The Civil Servants do not only do technical things well and professionally, but they also should do the right things ethically. All people will face ethical dilemma in their private and professional life; the question is that, are ready to face this because it is not easy to face ethical dilemma.

Educated people admit the importance of ethics, yet few of them comprehend this and acting ethically. Theoretically and practically, ethics can only be discussed and implemented meaningfully when it is fully comprehended. This comprehension requires a person to be willingly learn again about the basic of philosophy and moral which are related to something covers ethical study. As stated by Mill, Right and Salah: “We do not say mistake, unless we mean to imply that someone should be punished for any means because of doing that; if not by law, with the opinion of fellow beings; at least, by the reproach of his own conscience" (Mill, 1861).

Table 1.

Greek cardinal virtues. (Courtesy of Ellie Blazer. Adapted from Dreisbach, C. 2009. Ethics in criminal justice, New York: McGraw-Hill.)

\begin{tabular}{|l|l|}
\hline Ethics & Morals \\
\hline $\begin{array}{l}\text { Derived from Latin word moralis, } \\
\text { meaning "traditional customs" }\end{array}$ & $\begin{array}{l}\text { Derived from the Greek word, ethos, } \\
\text { meaning moral character }\end{array}$ \\
\hline $\begin{array}{l}\text { Typically associated with personal } \\
\text { behavior }\end{array}$ & $\begin{array}{l}\text { Typically refers to professional practices } \\
\text { and behavior }\end{array}$ \\
\hline $\begin{array}{l}\text { Customs or manners practiced in any } \\
\text { given community or culture }\end{array}$ & Conveys sense of stability/permanence \\
\hline May be different from culture to culture & An absolute standard of behavior \\
\hline $\begin{array}{l}\text { May change as acceptable social behavior } \\
\text { as the culture(s) change }\end{array}$ & $\begin{array}{l}\text { Standard is universal and immutable (not } \\
\text { subject to change) }\end{array}$ \\
\hline
\end{tabular}

Source: Ethics VS Morals (Dreisbach, C, 2009)

In the study of ethics, it is known the differentiation of ethics, first normative ethics which discusses moral values that should be determined (What is right for the people?). 
Descriptive ethics is about what moral is actually followed or obeyed (How should an individual act?), and Meta-ethics that is the basic character of ethics, including having objective justification, how an individual determines for his/herself, what social norm that should be followed (What ever happened, that is "right"?). Ethics involves the effort to answer question about how the moral result can be achieved. Sometimes it is called as "applied ethics". In other side, moral and ethics should be differentiated from law. Proven or not violating the law, it does not mean the individual right/wrong violating the moral and ethics. Indeed, legality does not imply morality, illegality also does not imply amorality.

Picture 1.

The relationship among ethics, morality and law (courtesy of Laura Rider Dutelle)

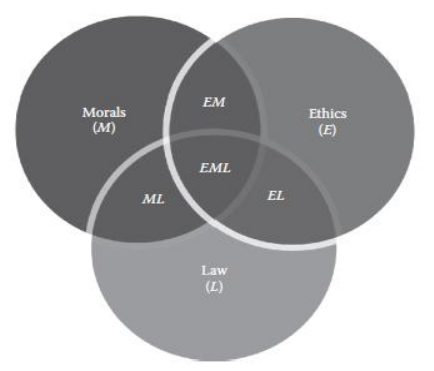

The above picture describes intersection of three circles, representing three different areas, which produce seven areas of classification. These fields reflect that there are decision, choice, and consideration that may be moral, ethics, or legal, or combination of them. Even, any action or decision made by an individual by the end will fall into one of this seven classification. Recognition in which an individual decision or choice will fall is important, so to find if it is exactly the one for the given scenario. In which the choice or decision is placed, in picture, will determine whether it is acceptable, unacceptable, rejected or neutral.

\section{Ethics in Public Service}

In public service, there is hierarchy related to any ethic level of which has its own series of responsibility and complexity. In the initial step, it is in form of personal morality, or right and wrong individual concept which is affected by the environment of family, social and learning experience process. Furthermore, professional ethics which is formed in an organization or professional association related to organization or position. The next level is organization which covers written policy and procedure which determine organization goal related to ethical and behavioral decision. Lastly, there is social ethics which is determined as 
social punishment which can be part of an individual personal social conscience (Shafritz, J.M., W. Russell and C.P Borick, 2007).

Accountability refers to professional public service which is responsible to someone. Integrity is obedience to principle and moral integrity and moral wisdom ethics into decision and action of someone. Responsibility is reliable action or accountability burden because of conducting something. An individual has no way to control or predict his/her action, and because of it his/her action could not be blamed morally. However, if there is an individual who is not bound to cross the same location and decide to drop something, which causes it is damaged, then he/she will be responsible causally or morally for the damage. Therefore, there are four basic requirements that should be existed in order to decide on moral responsibility:

1. An individual should be aware of the fact related to the situation or decision.

2. An individual should be aware the difference between right and wrong.

3. The individual should have motive to do his/her action.

4. The individual should be able to do anything beside what he/she does.

As part of the natural law that what remains is change, as proposed by Herakleitos, ethical culture has adapted and remains dynamic on the cross-history journey. In the beginning, there were some focal points that remain important; Value of Human and Uniqueness, every individual is believed to have inherent value that does not depend on the value of what they do. Everyone has the right to dignity and respect, as well as appreciation and deserved to be supported. Rising the Best, means always acting to get the best from other people, and thus someone is bound to ethical culture which is built together. In the concept formation, Adler used the term The Ethical Manifold to refer on how someone believes that this universe consists of unique moral and crucially needs individuals who has effect on other individuals, which could not be measured or predicted, but inherently exist. It shows interrelated individual ethically (Adler, 1918).

Cultural ethics has basis on premise that life could not be separated from "with and respect ethics." This principle is the core of what needed to live satisfying life as well as meaningful life while helping to create better and positive life for all individuals. Although those who believe in ethical culture perspective generally share common belief about ethical and non-ethical behavior, in which individual is pushed to recognize complexity of the problem, and thus, remain opened for dialogue as well as to avoid inflexibility or 
inadaptability. Living together when the civilization has changed marked by digitalization which demanding openness, mutual involvement and responsibility so the goal of ethical culture is inevitability. Living together to serve each other needs the following things:

1. Supremacy of moral purpose above all human purposes

2. Moral law has direct authority which is not dependable on dogma or philosophical theory.

3. Sciences and arts are directed to the true life.

Member of the society is pushed to obey religion, whatever the doctrine that suits them. Central concept is individual encouragement to always act so getting the best from others, and thus, within themselves. Although not all decisions given to other people are ethical, however it has basis in any categories of ethical perspectives. Every category of ethical perspectives identifies different standard or perspective in making decision and each of them refers to some preferred interests or different preferences, there is temptation to judge other's choice and decision to be "unethical" or "wrong."

Ethical behavior is the basis for every professional organization. In law enforcement, many courses that discuss ethics which may be good, but there is no knowledge about ethical ideology from the bureaucrat of Civil Servants who are taught. Any division in a department may need different ethical framework because of the unit in which the bureaucrat is assigned. Patrol bureaucrat has different necessity compared to bureaucrats of narcotics, school human resources, bureaucrat traffic, or SWAT bureaucrat. It makes "one stop shopping" ethical training is not practical or efficient (Bayley, 2009)

\section{Indonesian Corruption}

Corruption is categorized as extraordinary crime, it is not just because of the modus and systematic technique, the consequences of this crime is parallel and undermine all life systems, i.e. economy, politic, culture-social, and even moral as well as people mentality. The damage of economic life system will harm the state because it disturbs the state economy. Definition of the state here is not about the central government but also local government because it could not be avoided that the power both in the central and local government easier tend to be corrupted (Rukmini, 2010). 
In general, criminology stated that the cause of individual to commit corruption is influenced by internal factor, i.e. factor that is from themselves, and external factor, i.e. factor that is from outside of them.

1. Internal Factor, i.e.: human greedy, weak moral, insufficient income, urgent living needs, consumptive life style, non-implemented religious teaching.

2. External factor, i.e.: factor of people attitudes on corruption such as: values and culture in the society that support the existence of corruption. People consider that the victim of corruption is the State, even though in the end the biggest loss is experienced by the people themselves. The people do not aware that themselves are involved in corruption attitude. People do not really aware that corruption could be prevented and eradicated if the people are active in the agenda of prevention and eradication of corruption, Economy, Political and Organizational Factors, such as: lack of exemplary character of the leaders, there is no right organizational culture, inadequate the right accountability system in government institution, the weak of management controlling system, management tends to cover corruption in the organization (Kristian and Yopi Gunawan, 2015).

Other factor that stimulate corruption is the existence of the tradition of giving gifts to government officials and the importance of family ties in the culture of developing country. Besides that, in Indonesian culture, the first obligation of the person is taking care the closest brother/sister, and then the breeds or other ethnic group. So, if there is a brother/sister coming to the official for special treatment is difficult to deny. The denial can be interpreted as denial of traditional obligation. However, following the proposal means denying the formal law norms, i.e. West Law. So, there is always value conflict, i.e. between family interest and public interest.

Law factor provides opportunity to the law enforcement officers, in which they can different punishment about the element of each Articles so they could use this opportunity by considering that the element of the Article is not fulfilled and could decrease the punishment of the corruptor. This action of the officers makes the people perspectives becomes bad and disappointing with the local government performance.

Inner human control becomes the main key. If the inner control is improved and wellformed so the number of salary/wages will not tempt the officer to commit action forbid by 
religion or law. If the social control has been improved so the commitment in working will follow because if someone has committed to the job so he/she will do the best for the job and office, as well as he/she will not harm and damage the office by taking more income or living in luxury without considering the source of it. The law enforcement officers should be firm in eradicating corruption so it will be an example for other people. There are two factors of corruption, namely:

1. Greediness of the officers raises corruption. It is caused by the opportunity to commit fraud for fulfilling the excessive living needs.

2. Law Factor. It can be seen from two sides; in one side is the regulations aspect and the other side is the weak law enforcement.

3. Factor that triggered corruption of fictive Civil Servant salary in Lampung Utara government is the place or social environment from the corruptor which influenced the criminal behavior.

4. Factor of weak corruption regulations, which covers regulations that accommodate particular parties, inadequate quality of laws and regulations, less socialization of the regulations, low sanctions, inconsistency punishment and not-neutral, weak evaluation and revision of laws and regulations.

Corruption in public service has become serious problem in Indonesia. Corruption in the context of public service is caused by two main factors, namely external and internal factor. External factor is caused by the necessity of the people to get fast service in any issues such as permit processing. Long and red-tape bureaucracy level stimulate the people to be impatient and desire to have fast and efficient process. Meanwhile, internal factor more emphasizes on phenomenon of long bureaucracy level which is used by the bad officers in bureaucracy to get illegal benefits.

Many corruptions in bureaucracy which are investigated by Corruption Eradication Commission $(K P K)$ occurred because of different interest between bureaucrat and entrepreneurs. Many entrepreneurs want to process the business permit to be as fast as possible while the bureaucrats want to process based on the procedure. Therefore, the process of business permit takes long time. Here, there is negotiation process between bureaucrat and entrepreneurs. This circumstance creates corruption. Therefore, bureaucracy process should 
be reformed. So, the entrepreneurs do not fraud bureaucrat to make the business permit faster. The followings are the data of entrepreneurs from private sector involved in corruption.

\section{Picture 2.}

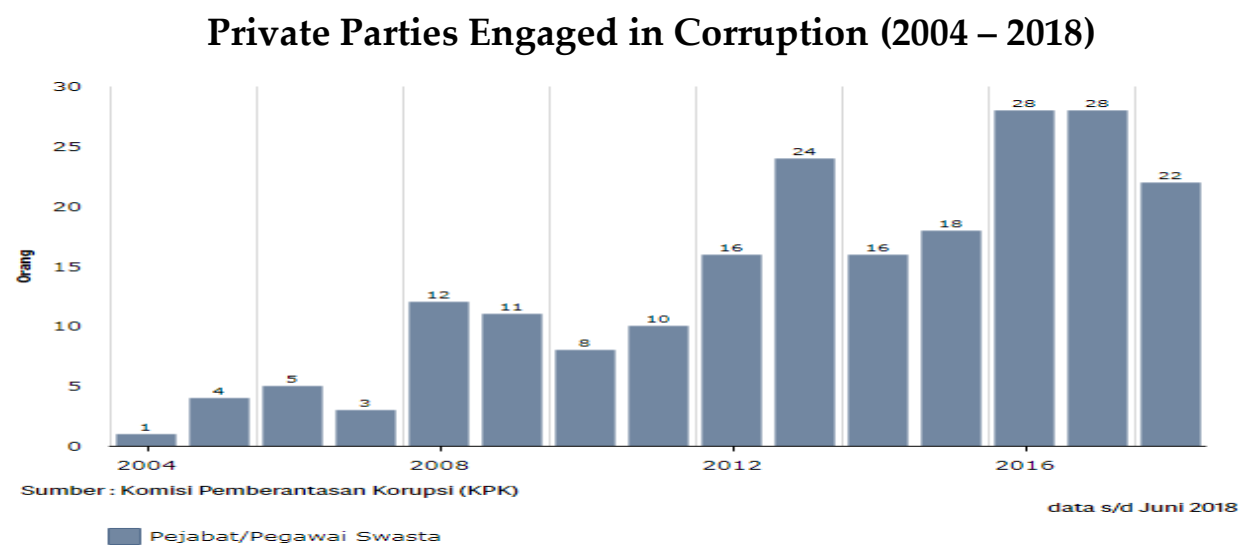

In this case, bureaucracy reformation requires many innovations in public service. These innovations should utilize the present technology so the service could be fast, clean and good. "One of the innovations done by the government is creating Mal Pelayanan Publik (Public Service Mall). This mall synergizes all of the existing services. It is intended to make the service becomes fast and successful, beneficial as well as good", Kalla said. So, the good, fast and clean governance can be realized. Moratorium for bureaucracy efficiency should be done. Some of the actions related to Civil Servant recruitment which is administrative, office building, and regional expansion. The government has cracked down bureaucracy in Indonesia. The following data is about the Governors who were arrested by KPK.

\section{Picture 3.}

The Number of Governor Arrested by KPK (2004 - 2017)

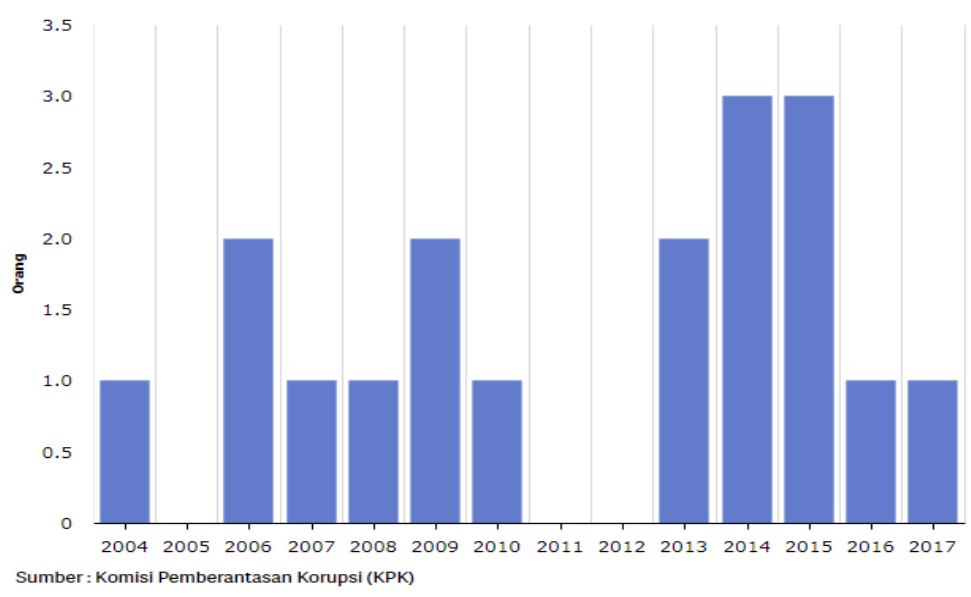


Meanwhile, KPK highlighted that there are many corruptors from Civil Servants. Based on data of National Civil Service Agency (BKN), from 2,764 Civil Servants who are involved in corruption and got court decision with a permanent legal force (inkracht), only 317 people have dismissed disrespectfully (fired). So, 2,357 corruptors are still active as Civil Servants. Since $1^{\text {st }}$ March 2018, KPK has officially informed $B K N$ to block data of those 2,357 Civil Servants. The Head of $K P K$, Agus Rahardjo said that dismissing disrespectfully the Civil Servants who are convicted of corruption should be done as soon as possible because there are two potential violations. First, it against Indonesian Law No 5 of 2014 concerning Civil Servant. Second, it potentially causes state loss. It is because the convicted Civil Servants have stolen state money, yet they are still paid by the state. BKN claimed that they have blocked data of the 2,357 Civil Servants after receiving a letter from Deputy for Prevention of KPK dated $1^{\text {st }}$ March 2018.

Picture 4.

The Convicted of Corruption based on the Jobs

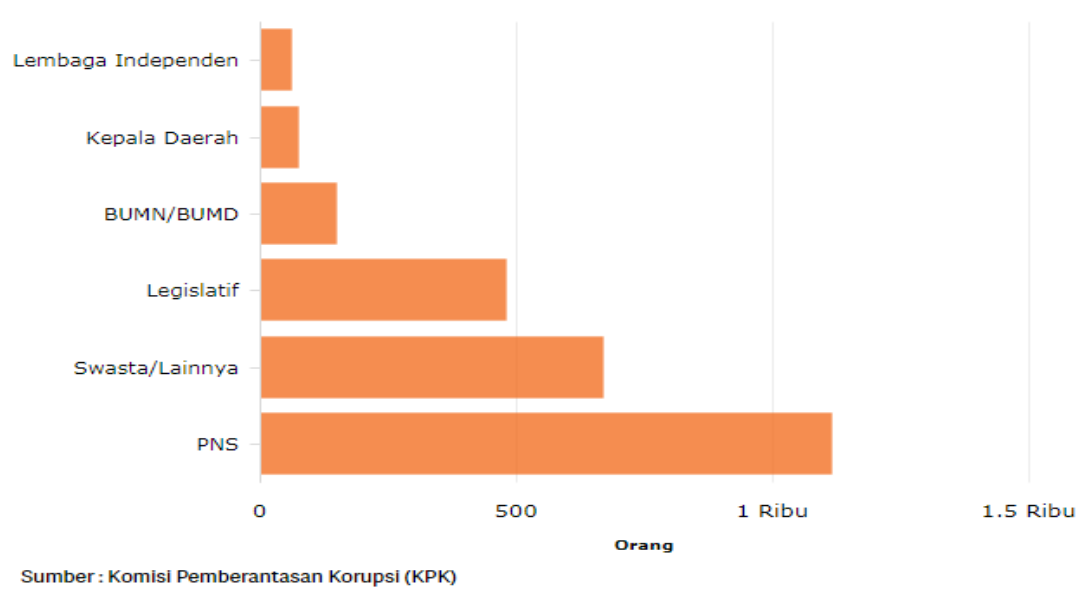

Data of Civil Servant convicted of corruption who are not dismissed disrespectfully are found in Regional Office of BKN Pekanbaru, in total of 301 Civil Servants who are already convicted of corruption by the court but are not dismissed disrespectfully. In Regional Office of $B K N$ Medan, there are 298 Civil Servants who are already convicted of corruption by the court but are not dismissed disrespectfully. Meanwhile, in In Regional Office of BKN Medan, there are 298 Civil Servants who are already convicted of corruption by the court but are not dismissed disrespectfully. In Regional Office of BKN Denpasar, there are 292 Civil Servants who are already convicted as corruptors. These corruptors are not fired yet because $B K N$ is 
difficult to trace their data. It is because the final court decision (inkracht) is only delivered to the parties concerned. Besides that, this final decision to the Civil Servants does not state the Employee ID Number. Other obstacle is that there is no integrated employee data crossing Ministry/Institution and local government. Meanwhile, there is regional leader as the Employee Supervisor Officer (PPK) who is not honest and let the Civil Servants who are convicted of corruption to be active. The situation of many convicted Civil Servants who are active because of the circular letter of Ministry of Home Affairs on 29 $9^{\text {th }}$ October 2012. This letter seems allowing the convicted corruptors to be in structural position. In integration data crosses Ministry/Institution and local government will be conducted.

Ethical framework is derived from two dominant framework of ethical work in Indonesia in the law enforcement ethics teaching. The first framework is idealism concept. This principle is based on belief that the desired result is always gained by using right action. The second framework is relativism concept. It is based on belief that all are relative upon certain circumstance and, because of that, the undesired result is a matter of life fact.

Book Corruption, Police Ethics, by Miller, Blackler, and Alexandra (2006), showed that there are three characteristics determining a good government officer. Here are the characteristics:

1. Having special skill.

2. Using this skill well morally.

3. For the right purpose morally.

As in other professions, not all Civil Servants are good. However, there is difference between failing to be good Civil Servant and becoming corruptive Civil Servant. For instance, incapability is considered as kind of corruption. Usually unexpectedly that incapability morally can be blamed, even in the case of directing to bad result, since someone could not be blamed because of failing to make something happened of which they are not capable of doing that. However, if this failure is caused by failing to complete themselves or training and acquiring the required skill and knowledge as they have the chance, they could be blamed morally.

Blaming is possible when an incapable individual continues to achieve the required job. One of the examples is that the retired-on duty. Senior officer who still works, but, as the consequence of laziness, tiredness, and probably any physical and mental problem, is not able 
to do his work well, but he keeps doing the job. Although it is not seen as corruption, being in the job because of personal reason, such as salary and insurance has negative effect for the institution and even can be considered as insecure and inappropriate use of Civil Servant authority and public property, which is considered as corruption.

Competent bureaucrat of Civil Servants can be considered as corruptive if they use their skill and knowledge illegally and immorally. For instance, a bureaucrat who is involved in illegal action could use his/her knowledge to manipulate data. Lastly, Civil Servants could be considered corruptive if they use appropriate knowledge and skill to achieve inappropriate result. For instance, providing premium service only for certain group of social and culture, which is not based on SOP.

There are some general conditions considered as contribution of Civil Servant corruption. Adaptation (Miller, S., J. Blackler, and A. Alexandra, 2006) may include:

1. The necessity and use of discretion authority by Civil Servant bureaucrat.

2. Road level interaction between law enforcement officer and corruptor who has motivation and interest in manipulating or corruptive Civil Servant.

3. Capability of the Civil Servant bureaucrat to use methods, such as fraud and coercion, which is usually considered immoral yet legal in their career.

4. Working and operation of law enforcement in a circumstance including amount of money, narcotics, weapons, and other valued items or those tempted to be abused or misused by external pressure.

5. A corrupt administration or leadership presence, sometimes combined with corruptive political and judicial system or seemingly futile.

6. Compensation is not worth to obligation and responsibility.

In profession of Civil Servant, tendency of corruption should be considered as basic work hazard and should be trained as well as treated as based on the task and assignment of Civil Servant as public servant (Miller et al., 2006). Steps that should be conducted to reduce corruption of Civil Servant, there are four basic fields that should be considered. It (adapted from Miller et al., 2006) includes the following fields: 1 . Recruiting and personnel recruitment, 2. Reducing opportunity for corruption, 3. Detection of corruption, 4 . Strengthening the effort to motivate individual to do the right action. It is clear that if Civil Servant tends to corrupt, it will become main concern for them to be chosen to have the highest moral character. It is 
important to reduce opportunity of corruption; however, the job characteristic of the Civil Servant could not fully reduce this opportunity.

Concerning on detection and even prevention of corruption, most of these actions are achieved through institutional accountability. This accountability method can be in form of internal and external accountability which covers complaint investigation, incident and report audit, supervision, and personnel checking. Responsibility method should include partnership involving Civil Servant and society. It makes sure that the people are able to make Civil Servant aware of the problem potential and asking for responsibility of Civil Servant on this problem.

The action of reducing corruption is important for the institution to support and announce their motivation to do what is morally right. It is obvious for the concerned people that reducing the opportunity of corruption is crucial. Morally, there is always people who are involved in illegal or immoral action, and thus, there always be necessity for technique of corruption detection. Therefore, it is suggested to the Head Officer of government, especially $B K D$ to act extraordinarily and spent time to motivate their personnel to conduct right things morally and give reward for those you have done right action morally as well as producing brilliant decision. Practically, there is no sophisticated detection that could prevent corruption unless moral issue. That's why it is wise to institutionalize reward and punishment system in Civil Servant institution to make decision and action which can motivate the personnel in conducting right action and prevent the personnel to make unethical decision, even corruption. Transparent promotion, adequate salary supported by good leadership as well as anti-corruption work culture will be a great strength in improving responsibility of the Civil Servant. The right implementation of the above values will be a strength in coordination chain, moral supporter for decision making and a support to reduce corruption.

The solidarity character of the Civil Servant could be strengthened. Positioning the emphasis on collective responsibility of Civil Servant to supervise their own strength in term of necessity and acceptance of correct moral in decision making. Civil Servant solidarity will build cooperative character and thus the corruption will be considered damaging bureaucrat organ. Rather than blind loyalty to partner, collective responsibility requires selective loyalty. It means maintain loyalty to people who do what is right, not to people who do what is wrong. This deep loyalty can only be guaranteed for them and by those who uphold the ideals and 
role of the bureaucracy and those who realize the ideals into their decision and action collectively. This collective responsibility also covers someone who is known as whistle blower, and correctly support, instead of hostile actions against people who have good intentions involved in whistle blower. Whistle-blower is "person who gives information to others or making disclosure of corruption or public error" (www.dictionary.com).

The above description describes that there are two strategies in effort to prevent and eradicate corruption: first, institutional strengthening of internal bureaucracy. It is done in order to actualize the professional bureaucracy. Professional bureaucracy should be conducted by implementing tight regulations and the implementation should be controlled by superiors strictly, and the bureaucracy service personnel should be adequately competent. Second, empowering the capacity of the human resources which supports the bureaucracy to get professional personnel. Professional human resource is personnel who works with adequate knowledge and skill as well as having superior integrity. This empowerment of human resource capacity is conducted through professional development program and character-building program.

\section{Conclusion}

Most of the bureaucrats do not involve in corruption scandal. However, massive complaint and scorn of the public in media news describe that public trust on bureaucracy and bad Civil servants has already in lowest level. Bureaucracy culture is still closed. This closed culture produces mistrust of incapability to have transparency in all level. This mistrust increased through massive belief that bureaucrats protect each other (Baldwin, 2007). The right training and recruitment process could minimize corruption potency in law enforcement. Through this training, besides improving individual and institutional moral, it also improved the service competence as required in the context of present public administration.

\section{References}

Adler, F. (1918). Philosophy Life on Ethics. New York: D. Aplenton and Co.

Baldwin, R. a. (2007). Ethical Climate Theory, whistle-blowing and the code of silence in police agencies in the State of Georgia. Jourusiness Ethicsnal of B, 70 (4): 341 - 361. 
Bayley, B. (2009, February 12). Improving ethics training for 21st century. Dipetik October 21, 2019, dari www.policeone.com.

Bertens, K. (1994). Etika. Jakarta: Gramedia.

Chaplin, J. (2006). Kamus Lengkap Psikolohi. Jakarta: PT. Raja Grafindo Persada.

Dreisbach, C. (2009). Ethic in Criminal Justice. New York: McGraw-Hill.

HUrloch, E. B. (1980). Development Psychology. Mc Grow Hill: Inc.

Janet V Denhard, Robert B Denhard. (2003). The New Public Servive : Serving Not Steering. New York: M.E Sharpe. Inc.

Kristian dan Yopi Gunawan. (2015). Tindak Pidana Koripsi Kajian terhadap Harmonisasi antara Hukum Nasional dan The United Nations Concention Agains Corupption (UNCAC). Bandung: PT Refika Aditama.

Mill, J. S. (1861). Utilitarianism. London: Parker, Son and Bourn.

Miller, S., J. Blackler, and A. Alexandra. (2006). Police Ethics. Crows Nest NSW. Australia: Allen \& Unwin.

Rukmini, M. (2010). Aspek Hukum Pidana dan Kriminologi. Bandung: Alumni.

Shafritz, J.M., W. Russell and C.P Borick. (2007). Introducing Public Administration, . New York: Pearson Longman, Inc. 